\title{
THE RELATION BETWEEN ENGAGEMENT QUALITY CONTROL REVIEW HOURS AND AUDITOR CHANGES: EVIDENCE FROM SOUTH KOREA
}

\author{
Jae-Won SONG, Yong-Shik KIM* \\ Business Administration School, Hansung University, Seoul, South Korea
}

Received 27 April 2020; accepted 22 February 2021

\begin{abstract}
The purpose of this study is to analyze whether engagement quality control review (EQCR) hours affect auditor changes and whether abnormal audit fees and changes in management have moderating effects on the relation between EQCR hours and auditor changes. The logit regression model is designed to investigate the relation between EQCR hours and auditor changes. The study finds evidence that EQCR hours are higher before auditors are changed. It also documents that abnormal audit fees weaken and that changes in management strengthen the positive relation between EQCR hours and auditor changes. In summary, high EQCR hours increase the probability of auditor changes, and the results imply that EQCR hours are a proxy for the audit risk perceived by auditors. This research is the first empirical study to test the relation between EQCR hours and auditor changes.
\end{abstract}

Keywords: engagement quality control review, auditor changes, audit fees, changes in management, audit hours, audit risk.

JEL Classification: M41, M42, M48.

\section{Introduction}

This study investigates the relation between engagement quality control review (EQCR) hours and auditor changes. The study predicts that EQCR hours are likely to affect auditor changes. It also predicts that audit fees and changes in management are likely to affect the relation between EQCR hours and auditor changes. It tests the relation between EQCR hours and auditor changes by collecting total audit hours including the EQCR hours disclosed in audit reports.

The International Federation of Accountants (IFAC) states that an EQCR is a particularly important part of maintaining and enhancing audit quality. Audit engagement teams have a responsibility to implement quality control procedures that are applicable to the audit

\footnotetext{
*Corresponding author. E-mail: jacob@hansung.ac.kr
} 
engagement and provide the firm with relevant information to enable the functioning of that part of the firm's system of quality control relating to independence (International Federation of Accountants [IFAC], 2009) (International Standards on Auditing (ISA) 220.3). EQCR is quality control procedures at the engagement level that provide the auditor with reasonable assurance (ISA 220.6).

Matsumura and Tucker (1995) argue that second partner reviews induce engagement partners to report with greater independence because second partner reviews increase the conservatism and objectivity of the engagement partners. Second partner reviews reduce reporting bias (Tucker \& Matsumura, 1997) and help audit firms avoid risky clients during the acceptance process (Ayers \& Kaplan, 2003), which suggests that second partner reviews play a significant role in reducing audit risk. Emby and Favere-Marchesi (2010) argue that the interaction between the engagement quality review (EQR) and engagement partners leads to a new and synergetic resolution of difficult and complex accounting issues.

This study focuses on the relation between EQCR hours and auditor changes. We predict that EQCR hours are likely to affect auditor changes for several reasons. First, EQCR hours are a proxy for the audit risk perceived by auditors (Bae et al., 2015; An \& Choe, 2017); thus, EQCR hours are likely to increase when audit risk is high. Second, auditors are likely to resign the following audit when audit risk is higher (Johnstone, 2000; Johnstone \& Bedard, 2003; Ghosh \& Tang, 2015). Third, firms are also likely to dismiss incumbent auditors when auditors perform a conservative audit process due to the high audit risk perceived by auditors (Krishnan, 1994; Mitra et al., 2016; DeFond \& Jiambalvo, 1994; DeFond \& Subramanyam, 1998; Lustgarten \& Shon, 2013).

The purpose of this study is to investigate whether EQCR hours affect auditor changes and whether abnormal audit fees and changes in management have moderating effects on the relation between EQCR hours and auditor changes. The study analyzes Korean firms for several reasons. First, Korean listed firms are supposed to disclose the EQCR hours and total audit hours in audit reports because since 2014, the Korean Act on External Audit of Stock Companies has required the disclosure of information on audit hours, including EQCR hours, which makes it possible to analyze the main hypotheses. Second, Korean listed firms also disclose audit fees in business reports; thus, it is able to investigate the moderating effect of abnormal audit fees on the relation between EQCR hours and auditor changes. Third, in South Korea, the International Financial Reporting Standards (IFRS) were adopted in 2011, and the International Standards on Auditing (ISA) were adopted in 2014; thus, it is able to test the main hypotheses under international and uniform accounting and audit standards. For these reasons, analyzing data from Korean firms will help us to clearly confirm the relation between EQCR hours and auditor changes.

The study finds that the results are the same as our expectations. First, it finds that EQCR hours increase auditor changes. Second, abnormal audit fees weaken the positive relation between EQCR hours and auditor changes. Third, changes in management strengthen the positive relation between EQCR hours and auditor changes. Finally, it finds that firms are more likely to change auditors when EQCR hours are high and discretionary accruals are low.

The results of this study provide several contributions. To the best of our knowledge, this research is the first empirical study to test the relation between EQCR hours and auditor 
changes. High EQCR hours imply that auditors perceive high audit risk, and it is expected that auditors conduct a more conservative audit process to achieve a desired level of audit risk when they perceive high audit risk. Therefore, this study hypothesizes that high EQCR hours increase auditor changes and finds that the results are in line with our expectations. The positive relation is weakened when the independence of auditors is impaired, while it is strengthened when disagreements between auditors and managers are great. It also documents that firms are more likely to change auditors when EQCR hours are high and discretionary accruals are low.

The remainder of this paper is organized as follows: The prior research is summarized, and hypotheses are developed in Section 2. Then, the research design and methods are discussed, including the samples and empirical models, in Section 3. Finally, the results are reported in Section 4, and the conclusions and limitations of this study are presented in last section.

\section{Literature review}

\subsection{Engagement quality control review (EQCR)}

Except for Korean studies, there are few studies that investigate the topic of EQCR hours because there are few countries that require disclosure of EQCR hours. Most EQCR-related studies investigate the effect and the role of the EQCR. Auditing Standard (AS) No. 7 requires an EQR for each audit engagement and states that a well-performed EQR can serve as an important safeguard against erroneous or insufficiently supported audit opinions and, accordingly, can contribute to audit quality (Public Company Accounting Oversight Board [PCAOB], 2009) (Release No. 2009-004). Emby and Favere-Marchesi (2010) argue that the EQR leads engagement partners to reach a new and synergetic resolution of difficult and complex accounting issues (e.g., income recognition/measurement, financial statement disclosure). Lennox et al. (2020) also argue that the ownership of EQ reviewers leads themselves to enhance audit quality because their primary role is to monitor audit quality.

The Securities and Exchange Commission (SEC) has required audit firms to institute second partner reviews for all audits of listed firms Since 1977 (American Institute of Certified Public Accountants [AICPA], 1986). Matsumura and Tucker (1995) argue that second partner reviews induce engagement partners to report with greater independence because second partner reviews increase the conservatism and objectivity of the engagement partners. Second partner reviews reduce reporting bias but do not completely eliminate it (Tucker \& Matsumura, 1997), and they help audit firms avoid risky clients during the acceptance process (Ayers \& Kaplan, 2003).

A few Korean studies investigate the relation between EQCR hours and earnings management. Bae et al. (2015) suppose that EQCR hours are a proxy for the audit risk perceived by auditors and find that EQCR hours are positively related to audit risk, measured by discretionary accruals. An and Choe (2017) also find that EQCR hours are positively related to the opportunistic behaviors of managers, measured by real activities earnings management. The results suggest that high earnings management increases EQCR hours to achieve a desired 
level of audit risk. Jeong and Lee (2019) find that EQCR hours improve audit quality when audit partner experience is shorter, which indicates that audit quality is more likely to be determined by EQCR hours when audit partners have short experience.

Gipper et al. (2020) find that audit quality is not associated with the audit partner tenure because total audit partner hours are higher in the last year on the tenure cycle even though both engagement and review partner hours decrease in the last year on the tenure cycle. Dodgson et al. (2020) also find that audit firm strategically plan the rotation of concurring review partners to help new engagement partners maintain the auditor-client relationship.

\subsection{Auditor changes}

There are various reasons why firms change auditors. The representative reasons for auditor changes are the high audit risk perceived by auditors, a conservative accounting and audit process, financial distress or earnings manipulation, and changes in management.

Prior research suggests that resignations reflect auditors' efforts to manage their risks (Catanach et al., 2011, p. 267). Johnstone (2000) and Johnstone and Bedard (2003) find that firms with high audit risk are less likely to be accepted by auditors. However, the use of specialists and increased billing rates moderate the negative relation between acceptance likelihood and audit risk (Johnstone \& Bedard, 2003). Ghosh and Tang (2015) find that audit risk and business risk, as well as litigation risk, are important factors for auditors' decisions on resignations and argue that auditors consider all three risk factors when they decide on resignations.

Mitra et al. (2016) argue that firms switch Big 4 auditors to non-Big 4 auditors due to conservatism and, thus, the quality of audit provided by non-Big 4 auditors after switching is likely to be lower. Krishnan (1994) investigates the relation between auditor switching and conservatism. Krishnan (1994) finds that firms switch auditors more frequently after receiving conservative judgments from ex-auditors, but they are unlikely to receive unqualified audit opinions after switching auditors because their negative information is revealed during the audit process.

DeFond and Jiambalvo (1994), DeFond and Subramanyam (1998), and Lustgarten and Shon (2013) investigate the effect of earnings manipulation on auditor changes. DeFond \& Jiambalvo (1994) argue that firms are likely to change auditors when they are willing to increase reporting earnings and incumbent auditors prevent earnings manipulation of their clients. DeFond and Subramanyam (1998) find that discretionary accruals decrease before auditor changes, while discretionary accruals increase in the year of auditor changes, which suggests that a conservative audit process induces auditor changes. Lustgarten and Shon (2013) argue that auditor changes are associated with both positive and negative discretionary accruals and suggest that auditors are likely to resign when discretionary accruals are higher and clients are likely to dismiss auditors when discretionary accruals are lower.

Changes in management also influence auditor changes. Beattie and Fearnley (1995) and Woo and Koh (2001) find that the relation between changes in management and auditor changes is positive. Beattie and Fearnley (1995) argue that changes in management are likely to lead to disagreements between new managers and incumbent auditors, which causes 
auditor changes. DeAngelo (1982) also argues that auditor-client disagreement on accounting standards such as SFAS-19 is an important determinant of auditor changes.

\section{Hypotheses development}

Audit risk increases audit hours (Bell et al., 2001) and is also likely to increase EQCR hours. Bae et al. (2015) and An and Choe (2017) find that auditors increase EQCR hours when the audit risk due to the opportunistic behaviors of managers is high. Auditors are willing to lower the detection risk and increase the input resources, such as EQCR hours, to achieve a desired level of audit risk when the inherent risk and control risk are high.

We predict that EQCR hours are likely to affect both the auditor resignations and dismissals. In the former prediction, EQCR hours are a proxy for the audit risk perceived by auditors (Bae et al., 2015; An \& Choe, 2017); thus, auditors are likely to resign the following audit when the loss is higher than the benefit from acceptance of risky clients (Ghosh \& Tang, 2015). In the latter prediction, the EQCR induces engagement partners to conduct the audit process more conservatively (Matsumura \& Tucker, 1995) to reduce audit risk (Tucker \& Matsumura, 1997; Ayers \& Kaplan, 2003); thus, firms are also likely to switch incumbent auditors when auditors conduct a conservative audit process (Krishnan, 1994; Mitra et al., 2016) to prevent earnings manipulation of their clients (DeFond \& Jiambalvo, 1994).

Therefore, high EQCR hours imply that auditors perceive high audit risk due to the opportunistic behaviors of managers and that auditors conduct a more conservative audit process to achieve a desired level of audit risk; thus, auditors are likely to be changed through either auditor resignations or dismissals when EQCR hours are high. The discussions above lead to the following hypothesis:

H1: EQCR hours are likely to be positively related to auditor changes.

DeAngelo (1981a) views abnormal audit fees as "client-specific quasi-rents". The reason why audit fees affect auditor independence is that abnormal audit fees represent a specific relation between auditors and clients (Higgs \& Skantz, 2006) and auditors' economic bond with clients (Kinney \& Libby, 2002). Dye (1991) and Choi et al. (2010) show that abnormal audit fees impair audit quality.

Copley et al. (1994) argue that the relation between audit fees and the audit quality demanded is not consistent with that between audit fees and the audit quality supplied and that higher audit fees are likely to reduce the levels of audit quality demanded. Therefore, it is possible to lower audit quality when the abnormal audit fees are high even though EQCR hours increase.

We consider two reasons for paying additional audit fees for high EQCR hours. One reason is to pay for high audit risk, which may impair auditor independence and fail to conduct a conservative audit process. The other is to pay for increased audit hours, including EQCR hours, which may strengthen auditors' economic bond with clients. Both reasons are likely to reduce the possibility of auditor changes despite high audit risk and EQCR hours. The discussions above lead to the following hypothesis:

$\mathrm{H}$ 2: Abnormal audit fees are likely to weaken the relation between EQCR hours and auditor changes. 
Most of the reasons for changes in management are consequences of poor performance (Warner et al., 1988; Weisbach, 1988). Therefore, new managers are willing to minimize the reported income in the year of changes in management and to defer positive income to subsequent periods. New managers take a "big bath" by using non-cash write-offs (DeAngelo, 1988) and discretionary accruals (Wells, 2002).

DeAngelo (1982) finds that petroleum firms increased the rate of auditor changes during the full cost/successful efforts controversy related to SFAS-19. Beattie and Fearnley (1995) and Woo and Koh (2001) empirically document that the relation between changes in management and auditor changes is positive. Beattie and Fearnley (1995) argue that changes in management are an important factor of auditor changes because new managers are likely to be dissatisfied with the audit services offered by incumbent auditors and to need additional audit services by new auditors.

Lei et al. (2000) find that auditor-client disagreements increase auditor resignations. New managers may have target accounting earnings in the year of changes in management and subsequent periods, and they may be willing to engage in earnings management. It is more likely that new managers change auditors when disagreements between new management and incumbent auditors as well as those between review partners and engagement partners are not compromised. Therefore, we expect that changes in management are more likely to result in auditor changes when EQCR hours are high. The discussions above lead to the following hypothesis:

H3: Changes in management are likely to strengthen the relation between EQCR hours and auditor changes.

\section{Research design}

\subsection{Models}

The purpose of this study is to investigate whether EQCR hours are positively related to auditor changes and whether abnormal audit fees and changes in management have moderating effects on the relation between EQCR hours and auditor changes. The logit regression model of auditor changes is designed as follows:

$$
\begin{aligned}
& A C_{i t}=\alpha_{0}+\alpha_{1} E Q C R H_{i t-1}+\alpha_{2} \operatorname{AbFEE}(M C)_{i t-1}+\alpha_{3} E Q C R H_{i t-1} \times A b F E E(M C)_{i t-1}+ \\
& \alpha_{4} S_{Z I E E_{i t-1}}+\alpha_{5} L E V_{i t-1}+\alpha_{6} R O A_{i t-1}+\alpha_{7} C F O_{i t-1}+\alpha_{8} G R O W_{i t-1}+\alpha_{9} B I G 4_{i t-1}+ \\
& \text { industry and yeardummies +errorterm, }
\end{aligned}
$$

where $A C_{i t}$ is a dummy variable that is one if firm $i$ changes auditors in year $t$ and zero otherwise. EQCRH $H_{i t-1}$ is EQCR hours divided by total audit hours ${ }^{1}$ including the EQCR hours of firm $i$ in year $t-1$. The hours of the engagement team, EQCR, and other specialists such as tax and valuation specialists who are necessary for the audit process are included in total audit hours. We expect the sign of the coefficient $E Q C R H_{i t-1}$ to be positive because

\footnotetext{
1 The hours of the engagement team, EQCR, and other specialists such as tax and valuation specialists who are necessary for the audit process are included in total audit hours.
} 
firms are likely to change auditors when EQCR hours are high. $M C_{i t-1}$ is a dummy variable that is one if firm $i$ changes its CEO in year $t-1$ and zero otherwise. We expect the sign of the coefficient $E Q C R H_{i t-1} \times M C_{i t-1}$ to be positive because changes in management are more likely to lead to disagreements between managers and auditors. Kinney and Libby (2002) argue that abnormal audit fees can capture the economic bond between auditors and clients better than normal audit fees. We calculate abnormal audit fees from the following ordinary least squares (OLS) regression model:

$$
\begin{aligned}
& \text { FEE }_{i t}=\gamma_{0}+\gamma_{1} \text { SIZE }_{i t-1}+\gamma_{2} \text { INVREC }_{i t-1}+\gamma_{3} L_{E V_{i t-1}}+\gamma_{4} \text { LIQUID }_{i t-1}+ \\
& \gamma_{5} \text { ROA }_{i t-1}+\gamma_{6} \text { LOSS }_{i t-1}+\gamma_{7} \text { FIRST }_{i t-1}+\gamma_{8} \operatorname{CON}_{i t-1}+\gamma_{9} \text { BIG }_{i t-1}+ \\
& \text { industryand yeardummies }+ \text { errorterm, }
\end{aligned}
$$

where $F E E_{i t}$ is the natural $\log$ of the audit fees of firm $i$ in year $t . A b F E E_{i t}$ is calculated by the differences between $F E E_{i t}$ and the normal audit fees calculated by Eq. (2). We expect the sign of the coefficient $E Q C R H_{i t-1} \times A b F E E_{i t-1}$ to be negative because the positive relation between EQCR hours and auditor changes is likely to weaken when abnormal audit fees are high and auditor independence is impaired.

In Eq. (1), we choose firm size $\left(S I Z E_{i t-1}\right)$, debt ratio $\left(L E V_{i t-1}\right)$, profitability $\left(R O A_{i t-1}\right)$, operating cash flows $\left(C F O_{i t-1}\right)$, sales growth $\left(G R O W_{i t-1}\right)$, and auditor size $\left(B I G 4_{i t-1}\right)$, which are likely to affect auditor changes. SIZE, a proxy for the costs of auditor changes, is expected to be negative (Francis \& Wilson, 1988; Carcello et al., 2002). LEV, a proxy for financial distress and high audit risk, is expected to be positive (Schwartz \& Menon, 1985). ROA and CFO, proxies for financial soundness and low audit risk, are expected to be negative (Choi et al., 2010). GROW, a proxy for demand for higher audit quality, is expected to be positive, and BIG4, a proxy for auditor size, is expected to be negative (DeAngelo, 1981b).

In Eq. (2), we also choose firm size $\left(S I Z E_{i t-1}\right)$, inventories and receivables ratio $\left(I N V R E C_{i t-1}\right)$, debt ratio $\left(L E V_{i t-1}\right)$, current assets ratio $\left(L I Q U I D_{i t-1}\right)$, profitability $\left(R O A_{i t-1}\right)$, negative reported earnings $\left(\operatorname{LOSS}_{i t-1}\right)$, initial audit $\left(F I R S T_{i t-1}\right)$, audit complexity $\left(C O N_{i t-1}\right)$, and auditor size $\left(B I G 4_{i t-1}\right)$, which are likely to affect audit fees. We include SIZE to control for firm size and omitted variables in Eq. (2). INVREC, a proxy for audit risk, and CON, a proxy for audit complexity, are expected to be positive (Simunic, 1980; Beattie et al., 2001). LEV and LOSS, proxies for financial distress, are expected to be positive, while LIQUID and ROA, proxies for financial soundness, are expected to be negative (Simunic \& Stein, 1996; Choi et al., 2010). FIRST, a proxy for low balling, is expected to be negative, and BIG4, a proxy for audit quality, is expected to be positive (DeAngelo, 1981a). In both Eqs (1) and (2), we also include industry and year dummies to control for industry and yearly differences. ${ }^{2}$

We hand collect the data on audit hours from audit reports and audit fees from business reports in Data Analysis, Retrieval and Transfer System [DART] (n.d.), the Korean public electronic disclosure website. We also obtain auditor changes, changes in

\footnotetext{
${ }^{2}$ It is possible that the results show in some industries and not in other industries. Therefore, industry dummies are included in the models to control for industry difference.
} 
management, and financial data from FN-GUIDE (n.d.), a database of financial information on Korean firms. The relevance of the data is still maintained because the data used in the study are disclosed in accordance with the Korean Act on External Audit of Stock Companies in effect so far.

\subsection{Sample selection}

We select firms listed on the Korea Composite Stock Price Index (KOSPI) and the Korea Securities Dealers Automated Quotations (KOSDAQ) between 2014 and $2016^{3}$ because since 2014, the Korean Act on External Audit of Stock Companies has required the disclosure of EQCR hours in audit reports. The sample is restricted to non-financial firms to ensure homogeneity. We remove firms that did not receive external audits and that received qualified opinions. We also remove firms without financial data, EQCR hours, and audit fees. The final sample consists of 4,580 firm-year observations. We winsorize all variables at 1 and 99 percent except for dummy variables. Table 1 reports a summary of the sample selection procedure.

Table 1. Sample selection procedure

Panel A: Sample selection procedure

\begin{tabular}{|l|c|}
\hline \multicolumn{1}{|c|}{ Description } & Number of firms \\
\hline Firms listed on the KOSPI and the KOSDAQ between 2014 and 2016 & 5,744 \\
\hline Less: Financial industry & $(593)$ \\
\hline No external audit & $(321)$ \\
\hline Qualified audit opinion & $(19)$ \\
\hline Data shortage (financial data, EQCR hours, and audit fees) & $(231)$ \\
\hline Final sample & 4,580 \\
\hline
\end{tabular}

\section{Results}

\subsection{Descriptive statistics}

The descriptive statistics of the variablles used in this study are reported in Table 2 . The mean (median) of auditor changes $\left(A C_{i t}\right)$ is $0.184(0.000)$, which means that on average, approximately 18 percent of Korean listed firms change auditors. The mean (median) of EQCR hours $\left(E Q C R H_{i t-1}\right)$ is $0.018(0.015)$, which means that on average, EQCR hours are approximately 1.8 percent of total audit hours. The mean (median) of abnormal audit fees $\left(A b F E E_{i t-1}\right)$ is $-0.001(-0.002)$. The mean (median) of changes in management $\left(M C_{i t-1}\right)$ is $0.309(0.000)$, which means that on average, approximately 31 percent of the listed firms in our sample change their CEOs.

\footnotetext{
${ }^{3}$ While the period of sample ends in 2016, the data on auditor changes of FY 2017 are needed to use the dependent variable in the following year. We began our study in 2018, so we used the data until FY 2017.
} 
Table 2. Descriptive statistics $(\mathrm{N}=4,580)$

\begin{tabular}{|l|c|c|c|c|c|}
\hline \multicolumn{1}{|c|}{ Variables } & Mean & Std. Dev. & Minimum & Median & Maximum \\
\hline$A C_{i t}$ & 0.184 & 0.388 & 0.000 & 0.000 & 1.000 \\
\hline$E Q C R H_{i t-1}$ & 0.018 & 0.012 & 0.003 & 0.015 & 0.066 \\
\hline$A b F E E_{i t-1}$ & -0.001 & 0.363 & -1.030 & -0.002 & 0.970 \\
\hline$M C_{i t-1}$ & 0.309 & 0.462 & 0.000 & 0.000 & 1.000 \\
\hline$S I Z E_{i t-1}$ & 8.290 & 0.628 & 7.163 & 8.165 & 10.569 \\
\hline$L E V_{i t-1}$ & 42.224 & 20.747 & 5.411 & 42.106 & 93.538 \\
\hline$R O A_{i t-1}$ & 1.073 & 9.964 & -47.258 & 2.518 & 24.200 \\
\hline$C F O_{i t-1}$ & 4.671 & 8.757 & -27.503 & 5.063 & 29.333 \\
\hline$G R O W_{i t-1}$ & 7.952 & 34.732 & -57.218 & 2.951 & 215.021 \\
\hline$B I G 4_{i t-1}$ & 0.500 & 0.500 & 0.000 & 1.000 & 1.000 \\
\hline
\end{tabular}

Note: Variables are defined in the Appendix.

\subsection{Correlations}

The Pearson correlations of the main variables used in this study are reported in Table 3. $A C_{i t}$ and $E Q C R H_{i t-1}$ have a significantly positive association, which means that auditors are likely to be changed when the EQCR hours in the previous year are high. $A C_{i t}$ and $A b F E E_{i t-1}$ have a significantly positive association, which means that abnormal audit fees are high in the year before auditors are changed. $A C_{i t}$ and $M C_{i t-1}$ have an insignificant and negative association.

Meanwhile, the correlation coefficient between $S I Z E_{i t-1}$ and $F E E_{i t-1}$ is 0.778 (untabulated), leading to concerns about multicollinearity. Therefore, we verify the variance inflation factor (VIF) value while conducting pooled OLS regressions and confirm that the maximum VIF value is less than 4.0, which alleviates the concerns about multicollinearity.

\subsection{Main results}

Table 4 reports the results that indicate whether EQCR hours, abnormal audit fees, and changes in management affect auditor changes. In Model 1, we confirm hypothesis 1, which states that EQCR hours are likely to be positively related to auditor changes. In Model 2, we confirm hypothesis 2 , which states that audit fees are likely to weaken the relation between EQCR hours and auditor changes. In Model 3, we confirm hypothesis 3, which states that changes in management are likely to strengthen the relation between EQCR hours and auditor changes. The Chi-squares of all three models are significant $(p<0.001)$ and the Nagelkerke $R^{2}$ ranges between 0.103 and 0.119 , which indicates that the models fit. 


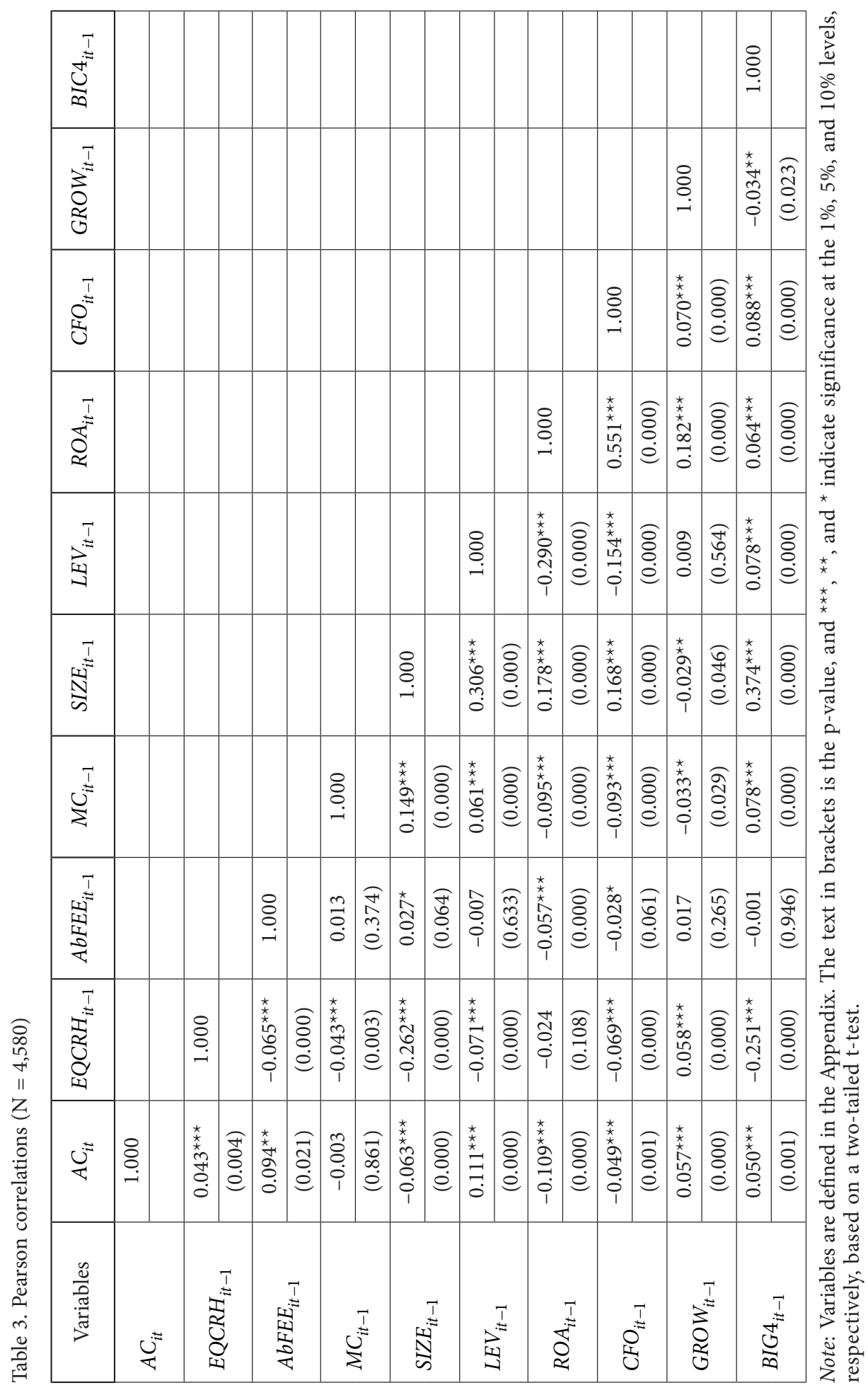


In Models 1, 2, and 3, the coefficients $E Q C R H_{i t-1}$ are significantly positive $(p<0.001$, $p<0.001$, and $p=0.037$, respectively). These results suggest that auditors are likely to be changed when the EQCR hours in the previous year are high, which lends support to the hypothesis H1. In Model 2, the coefficient $A b F E E_{i t-1}$ is significantly positive $(p<0.001)$, which means that abnormal audit fees are high in the year before auditors are changed. The result is consistent with Simon and Francis (1988) and Zhang (2018)'s finding that auditor

Table 4. Results for the effect of EQCR hours on auditor changes

\begin{tabular}{|c|c|c|c|c|}
\hline \multirow[b]{2}{*}{ Variables } & \multirow{2}{*}{$\begin{array}{c}\text { Expected } \\
\text { Sign }\end{array}$} & Model 1: & Model 2: & Model 3: \\
\hline & & $\begin{array}{l}\text { Coefficient } \\
\text { (wald value) }\end{array}$ & $\begin{array}{l}\text { Coefficient } \\
\text { (wald value) }\end{array}$ & $\begin{array}{l}\text { Coefficient } \\
\text { (wald value) }\end{array}$ \\
\hline Constant & $( \pm)$ & $\begin{array}{c}1.367 \\
(0.901)\end{array}$ & $\begin{array}{c}1.374 \\
(0.901)\end{array}$ & $\begin{array}{c}1.387 \\
(0.920)\end{array}$ \\
\hline$E Q C R H_{i t-1}$ & $(+)$ & $\begin{array}{c}12.291^{* * *} \\
(12.643)\end{array}$ & $\begin{array}{c}14.009^{* * *} \\
(16.263)\end{array}$ & $\begin{array}{l}8.603^{* *} \\
(4.334)\end{array}$ \\
\hline$A b F E E_{i t-1}$ & $(+)$ & - & $\begin{array}{l}1.002^{* * *} \\
(26.440)\end{array}$ & - \\
\hline$E Q C R H_{i t-1} \times A b F E E_{i t-1}$ & $(-)$ & - & $\begin{array}{c}-13.464^{*} \\
(2.754)\end{array}$ & - \\
\hline$M C_{i t-1}$ & $(+)$ & - & - & $\begin{array}{l}-0.247 \\
(2.387)\end{array}$ \\
\hline$E Q C R H_{i t-1} \times M C_{i t-1}$ & $(+)$ & - & - & $\begin{array}{l}11.754^{*} \\
(2.813)\end{array}$ \\
\hline$S I Z E_{i t-1}$ & $(-)$ & $\begin{array}{c}-0.523^{* * *} \\
(35.517)\end{array}$ & $\begin{array}{c}-0.538^{* * *} \\
(39.077)\end{array}$ & $\begin{array}{c}-0.518^{* * *} \\
(34.234)\end{array}$ \\
\hline$L E V_{i t-1}$ & $(+)$ & $\begin{array}{l}0.017^{* * *} \\
(54.676)\end{array}$ & $\begin{array}{l}0.017^{* * *} \\
(57.287)\end{array}$ & $\begin{array}{l}0.017^{* * *} \\
(54.822)\end{array}$ \\
\hline$R O A_{i t-1}$ & $(-)$ & $\begin{array}{c}-0.018^{* * *} \\
(14.770)\end{array}$ & $\begin{array}{c}-0.017^{* * *} \\
(12.132)\end{array}$ & $\begin{array}{c}-0.018^{* * *} \\
(14.646)\end{array}$ \\
\hline$C F O_{i t-1}$ & $(-)$ & $\begin{array}{l}0.009^{*} \\
(2.814)\end{array}$ & $\begin{array}{l}0.009^{*} \\
(2.827)\end{array}$ & $\begin{array}{l}0.009^{*} \\
(2.881)\end{array}$ \\
\hline$G R O W_{i t-1}$ & $(+)$ & $\begin{array}{l}0.004^{* * *} \\
(12.286)\end{array}$ & $\begin{array}{l}0.004^{\star * *} \\
(11.056)\end{array}$ & $\begin{array}{l}0.004^{* * *} \\
(12.449)\end{array}$ \\
\hline$B I G 4_{i t-1}$ & $(-)$ & $\begin{array}{l}0.598^{* * *} \\
(45.351)\end{array}$ & $\begin{array}{l}0.626^{* * *} \\
(48.693)\end{array}$ & $\begin{array}{l}0.595^{\star * *} \\
(44.939)\end{array}$ \\
\hline IND_Dummy & & Include & Include & Include \\
\hline YEAR_Dummy & & Include & Include & Include \\
\hline Chi-square & & $299.3^{x * \star}$ & $347.1^{\star * *}$ & $302.2^{\star * *}$ \\
\hline Nagelkerke $R^{2}$ & & 0.103 & 0.119 & 0.104 \\
\hline $\mathrm{N}$ & & 4,580 & 4,580 & 4,580 \\
\hline
\end{tabular}

Note: Variables are defined in the Appendix. The text in brackets is the Wald value, and ${ }^{* * *}{ }^{* *}$, and * indicate significance at the $1 \%, 5 \%$, and $10 \%$ levels, respectively. 
tenure increases audit fees. The coefficient $E Q C R H_{i t-1} \times A b F E E_{i t-1}$ is significantly negative $(p=0.097)$, which means that abnormal audit fees weaken the positive relation between EQCR hours and auditor changes, supporting the hypothesis H2. In Model 3, the coefficient $M C_{i t-1}$ is insignificantly negative, which means that changes in management may not significantly affect auditor changes. The coefficient $E Q C R H_{i t-1} \times M C_{i t-1}$ is significantly positive $(p=0.094)$, which means that changes in management strengthen the positive relation between EQCR hours and auditor changes, supporting the hypothesis H3.

As a whole, the study finds a positive relation between EQCR hours and auditor changes. It also finds that abnormal audit fees weaken the positive relation between EQCR hours and auditor changes and that changes in management strengthen the positive relation between EQCR hours and auditor changes. Therefore, we conclude that the audit risk perceived by auditors increases auditor changes. We argue that impaired auditor independence decreases auditor changes and that disagreements between new managers and incumbent auditors further increase auditor changes when auditors perceive high audit risk.

With respect to the control variables used in Models 1, 2, and 3, SIZE $E_{i t-1}$ and $R O A_{i t-1}$ are negatively associated with auditor changes, and $L E V_{i t-1}$ and $G R O W_{i t-1}$ are positively associated with auditor changes. These results indicate that financial distress such as closeness to debt covenants increases auditor changes. $C F O_{i t-1}$ and $B I G 4_{i t-1}$ are positively associated with audit changes, which is different from our expectations.

\subsection{Additional analysis}

\subsubsection{Earnings management}

DeFond and Jiambalvo (1994) and DeFond and Subramanyam (1998) argue that firms are likely to switch auditors when auditors conduct a conservative audit process. In addition, the study tests whether auditor changes are more frequent when EQCR hours are high and discretionary accruals are low and whether auditor changes are less frequent when EQCR hours are low and discretionary accruals are high. We use dummy variables to represent the joint effect of a conservative audit process and audit risk on auditor changes in Eq. (3) as follows:

$$
\begin{aligned}
& A C_{i t}=\alpha_{0}+\alpha_{1} E Q H D A L_{i t-1}+\alpha_{2} S I Z E_{i t-1}+\alpha_{3} L E V_{i t-1}+\alpha_{4} R O A_{i t-1}+ \\
& \alpha_{5} C_{i t-1}+\alpha_{6} G R O W_{i t-1}+\alpha_{7} B I G 4_{i t-1}+\text { industryand yeardummies }+ \\
& \text { errorterm, }
\end{aligned}
$$

where $E Q H D A L_{i t-1}$ is a dummy variable that is one if the EQCR hours of firm $i$ are high and discretionary accruals are low in year $t-1$ and zero otherwise.

As shown in Table 5, the coefficient $E Q H D A L_{i t-1}$ is significantly positive $(p=0.063)$. The results show that firms are more likely to change auditors when EQCR hours are high and discretionary accruals low, which suggests that the joint effect of a conservative audit process and high audit risk further affects auditor changes. 
Table 5. Results for the joint effect of EQCR hours and discretionary accruals on auditor changes

\begin{tabular}{|l|c|c|}
\hline \multicolumn{1}{|c|}{ Variables } & \multirow{2}{*}{ Expected Sign } & Model 1: $A C_{t}$ \\
\cline { 3 - 3 } & & Coefficient (wald value) \\
\hline Constant & $( \pm)$ & $\begin{array}{c}1.802 \\
(1.564)\end{array}$ \\
\hline EQHDAL $L_{\text {it }-1}$ & $(+)$ & $\begin{array}{c}0.178^{*} \\
(3.448)\end{array}$ \\
\hline Othervariables & & Include \\
\hline Chi-square & & $290.519^{* * *}$ \\
\hline Nagelkerke $R^{2}$ & & 0.100 \\
\hline $\mathrm{N}$ & & 4,580 \\
\hline
\end{tabular}

Note: Variables are defined in the Appendix. The text in brackets is the Wald value, and ${ }^{* *}$, ${ }^{* *}$, and * indicate significance at the $1 \%, 5 \%$, and $10 \%$ levels, respectively.

\subsubsection{Self-selection}

It is possible that the audit risk of firms in the sample with auditor changes is inherently high regardless of the probability of auditor changes; thus, their EQCR hours are higher than those of firms in the sample without auditor changes, leading to concerns about self-selection. Therefore, we create a sample based on the year in which auditors were changed (treatment sample) and the year in which auditors were not changed (control sample) using only the sample with auditor changes. In untabulated results, the statistical significances are lower than those in Table 4, but all the signs are the same as those of our prediction. Therefore, we conclude that the results alleviate the concerns about self-selection.

\subsubsection{Direction of auditor changes}

Additionally, the study analyzes the difference in EQCR hours between upward (downward) and lateral auditor changes. Becker et al. (1998) find that the earnings management of firms audited by non-Big 6 auditors is higher than that of firms audited by Big 6 auditors. Davidson III et al. (2006) find that earnings management increases when firms change auditors from Big 6 to non-Big 6 auditors. Therefore, it is possible that EQCR hours decrease when firms change auditors from Big 4 to non-Big 4 auditors and that EQCR hours increase when firms change auditors from non-Big 4 to Big 4 auditors. In untabulated results from logit regression, it does not find significant differences in EQCR hours between upward and lateral (from non-Big 4 to non-Big 4) auditor changes or between downward and lateral (from Big 4 to Big 4) auditor changes. The results suggest that auditors do not differentially perceive audit risk between upward (downward) and lateral auditor changes.

\subsubsection{Business risk, litigation risk, and agency costs}

Finally, the study investigates whether business risk, litigation risk, and agency costs have moderating effects on the relation between EQCR hours and auditor changes. Ghosh and Tang (2015) argue that business risk, litigation risk, and audit risk are key factors when auditors decide on resignations. Francis and Wilson (1988) also argue that agency costs 
affect auditor choice. We divide our sample into KOSPI and KOSDAQ subsamples because the business risk of firms listed on KOSDAQ, similar to NASDAQ is higher than that of firms listed on KOSP (Sung, 2007). ${ }^{4}$ We use disclosures of the occurrence of litigation in year $t-1$ as a proxy for litigation risk. We divide the sample into chaebol firms and non-chaebol firms because the agency costs of chaebol firms are higher than those of nonchaebol firms (Bae et al., 2002). ${ }^{5}$ As shown in Models 1, 2, and 3 of Table 6, the coefficients $E Q C R H_{i t-1} \times$ BusinessR $_{i t-1}, E Q C R H_{i t-1} \times$ Litigation $_{i t-1}$, and $E Q C R H_{i t-1} \times A_{\text {gency }} C_{i t-1}$ are insignificant, which suggests that the interactions between audit risk and other risks have no further effect on auditor changes. It also finds that litigation risk and agency costs, as well as audit risk, have significant effects on auditor changes.

Table 6. Results for the effect of business risk, litigation risk, and agency costs on auditor changes

\begin{tabular}{|c|c|c|c|c|}
\hline \multirow[b]{2}{*}{ Variables } & \multirow{2}{*}{$\begin{array}{c}\text { Expected } \\
\text { Sign }\end{array}$} & Model 1: $A C_{t}$ & Model 2: $A C_{t}$ & Model 3: $A C_{t}$ \\
\hline & & $\begin{array}{c}\text { Coefficient } \\
\text { (wald value) }\end{array}$ & $\begin{array}{c}\text { Coefficient } \\
\text { (wald value) }\end{array}$ & $\begin{array}{c}\text { Coefficient } \\
\text { (wald value) }\end{array}$ \\
\hline Constant & $( \pm)$ & $\begin{array}{l}1.474 \\
(0.956)\end{array}$ & $\begin{array}{c}1.142 \\
(0.611)\end{array}$ & $\begin{array}{l}1.730 \\
(1.416)\end{array}$ \\
\hline$E Q C R H_{i t-1}$ & $(+)$ & $\begin{array}{c}13.823^{* *} \\
(3.939)\end{array}$ & $\begin{array}{c}13.165^{* * *} \\
(13.830)\end{array}$ & $\begin{array}{l}12.803^{* * *} \\
(13.198)\end{array}$ \\
\hline Business $R_{i t-1}$ & $(+)$ & $\begin{array}{l}-0.001 \\
(0.000)\end{array}$ & - & - \\
\hline$E Q C R H_{i t-1} \times$ Business $_{i t-1}$ & $( \pm)$ & $\begin{array}{l}-1.978 \\
(0.063)\end{array}$ & - & - \\
\hline Litigation $_{i t-1}$ & $(+)$ & - & $\begin{array}{l}0.713^{\star *} \\
(4.754)\end{array}$ & - \\
\hline$E{ }^{2} H_{i t-1} \times$ Litigation $_{i t-1}$ & $( \pm)$ & - & $\begin{array}{c}-16.118 \\
(1.145) \\
\end{array}$ & - \\
\hline AgencyC $_{i t-1}$ & $(+)$ & - & - & $\begin{array}{l}0.606^{*} \\
(3.446)\end{array}$ \\
\hline$E Q C R H_{i t-1} \times A_{g e n c y C} C_{i t-1}$ & $( \pm)$ & - & - & $\begin{array}{c}-18.418 \\
(0.965)\end{array}$ \\
\hline Othervariables & & Include & Include & Include \\
\hline Chi-square & & $299.499^{* * *}$ & $305.124^{* * *}$ & $303.681^{* * *}$ \\
\hline Nagelkerke $R^{2}$ & & 0.103 & 0.105 & 0.104 \\
\hline $\mathrm{N}$ & & 4,580 & 4,580 & 4,580 \\
\hline
\end{tabular}

Note: Variables are defined in the Appendix. The text in brackets is the Wald value, and ${ }^{* *},{ }^{* *}$, and * indicate significance at the $1 \%, 5 \%$, and $10 \%$ levels, respectively.

\footnotetext{
${ }^{4}$ The systemic market risk (beta) of firms listed on the KOSDAQ is higher than that of firms listed on the KOSPI because firms listed on the KOSDAQ are mostly small-sized venture firms compared to the sizable firms listed on the KOSPI (Sung, 2007).

${ }^{5}$ Controlling shareholders with minimal cash flow rights control the member firms of so-called "chaebol" Korean business groups, causing agency problems between controlling and minority shareholders (Bae et al., 2002). The representative management style of "chaebol" Korean business groups is such that the owners or their families (controlling shareholders) directly and indirectly manage the business groups and they operate various businesses in most industries to reduce operational costs through vertical integration (Kim et al., 2021).
} 


\section{Discussions}

In this study, the first hypothesis is that EQCR hours are likely to be positively related to auditor changes and it finds the positive relation between EQCR hours and auditor changes, which lends support to the first hypothesis. The second hypothesis is that abnormal audit fees are likely to weaken the relation between EQCR hours and auditor changes and it finds the results in line with the second hypothesis. The final hypothesis is that changes in management are likely to strengthen the relation between EQCR hours and auditor changes and find the moderating effect of changes in management on the relation between EQCR hours and auditor changes, which supports the third hypothesis.

The results suggest that high EQCR hours imply that auditors perceive high audit risk and auditors conduct a more conservative audit process, which leads to auditor changes. High abnormal audit fees impair the independence of auditors and weaken the positive relation between EQCR hours and auditor changes, while changes in management increase disagreements between auditors and managers and strengthen the positive relation between EQCR hours and auditor changes.

\section{Conclusions}

This study investigates whether EQCR hours affect auditor changes and whether audit fees and changes in management have moderating effects on the relation between EQCR hours and auditor changes. The sample consists of firms listed on the Korea Stock Exchange (KSE) between 2014 and 2016.

The study finds evidence, consistent with the hypotheses, that auditors are likely to be changed when the EQCR hours in the previous year are high. Abnormal audit fees weaken and changes in management strengthen the positive relation between EQCR hours and auditor changes. Additionally, it finds that firms are more likely to change auditors when EQCR hours are high and discretionary accruals are low.

The main contribution of this study is that it is first to empirically document the relation between EQCR hours and auditor changes. It also documents the moderating effects of abnormal audit fees and changes in management on the relation between EQCR hours and auditor changes. We conclude that the audit risk perceived by auditors increases auditor changes. We also argue that impaired auditor independence decreases auditor changes and that disagreements between new managers and incumbent auditors further increase auditor changes when auditors perceive high audit risk.

It would be worthwhile to investigate whether EQCR hours differentially affect auditor changes by type, for example, mandatory vs. voluntary auditor changes.

\section{Acknowledgements}

We thank the participants of the 2018 Korean Accounting Information Association Fall Conference. 


\section{Funding}

This research was financially supported by Hansung University.

\section{Author contributions}

Song conceived the study and was responsible for the design and development of the data analysis. Song was responsible for data collection and analysis. Song and Kim were responsible for data interpretation. Kim wrote the first draft of the article.

\section{Disclosure statement}

The authors declare no conflict of interest.

\section{References}

Ayers, S., \& Kaplan, S. E. (2003). Review partners' reactions to contact partner risk judgements of prospective clients. Auditing: A Journal of Practice \& Theory, 22(1), 29-45. https://doi.org/10.2308/aud.2003.22.1.29

American Institute of Certified Public Accountants. (1986). Division for CPA firms SEC practice section: SECPS manual. AICPA, New York.

An, H. L., \& Choe, K. H. (2017). The effects of managers' real earnings management activities on audit quality control review hours. Productivity Review, 31(4), 33-59 (in Korean). https://www.kci.go.kr/ kciportal/ci/sereArticleSearch/ciSereArtiView.kci?sereArticleSearchBean.artiId=ART002307139

Bae, G. S., Lee, J. E., Rho, J. H., \& Choi, S. U. (2015). Auditors' differential responses to audit risks through quality control review hours. Korean Accounting Review, 40(6), 81-117 (in Korean). http://kiss.kstudy.com/thesis/thesis-view.asp?key=3379968

Bae, K. H., Kang, J. K., \& Kim, J. M. (2002). Tunneling or value added? Evidence from mergers by Korean business groups. The Journal of Finance, 57(6), 2695-2740. https://doi.org/10.1111/1540-6261.00510

Beattie, V., \& Fearnley, S. (1995). The importance of audit firm characteristics and the drivers of auditor change in UK listed companies. Accounting and Business Research, 25(100), 227-239. https://doi.org/10.1080/00014788.1995.9729912

Beattie, V., Goodacre, A., Pratt, K., \& Stevenson, J. (2001). The determinants of audit fees: Evidence from the voluntary sector. Accounting and Business Research, 31(4), 243-274. https://doi.org/10.1080/00014788.2001.9729619

Becker, C. L., DeFond, M., Jiambalvo, J., \& Subramanyam, K. R. (1998). The effect of audit quality on earnings management. Contemporary Accounting Research, 15(1), 1-24. https://doi.org/10.1111/j.1911-3846.1998.tb00547.x

Bell, T. B., Landsman, W. R., \& Shackelford, D. S. (2001). Auditors' perceived business risk and audit fees: Analysis and evidence. Journal of Accounting Research, 39(1), 35-43. https://doi.org/10.1111/1475-679X.00002

Carcello, J. V., Hermanson D. R., Neal, T. L., \& Riley, R. A. (2002). Board characteristics and audit fees. Contemporary Accounting Research, 19(3), 365-384. https://doi.org/10.1506/CHWK-GMQ0-MLKE-K03V

Catanach, A., Irving, J. H., Williams, S. P., \& Walker, P. L. (2011). An ex post examination of auditor resignations. Accounting Horizons, 25(2), 267-283. https://doi.org/10.2308/acch-10030 
Choi, J. H., Kim, J. B., \& Zang, Y. (2010). Do abnormally high audit fees impair audit quality? Auditing: A Journal of Practice \& Theory, 29(2), 115-140. https://doi.org/10.2308/aud.2010.29.2.115

Copley, P. A., Doucet, M. S., \& Gaver, K. M. (1994). A simultaneous equations analysis of quality control review outcomes and engagement fees for audits of recipients of federal financial assistance. The Accounting Review, 69(1), 244-256. https://www.jstor.org/stable/248270

Data Analysis, Retrieval and Transfer System (DART) (n.d.). http://dart.fss.or.kr

Davidson III, W. N., Jiraporn, P., \& DaDalt, P. (2006). Causes and consequences of audit shopping: An analysis of auditor opinions, earnings management, and auditor changes. Quarterly Journal of Business and Economics, 45(1-2), 69-87. https://www.jstor.org/stable/40473415

DeAngelo, L. E. (1981b). Auditor size and audit quality. Journal of Accounting and Economics, 3(3), 183-199. https://doi.org/10.1016/0165-4101(81)90002-1

DeAngelo, L. E. (1982). Mandated successful efforts and auditor choice. Journal of Accounting and Economics, 4(3), 171-203. https://doi.org/10.1016/0165-4101(82)90008-8

DeAngelo, L. E. (1988). Managerial competition, information costs, and corporate governance: The use of accounting performance measures in proxy contests. Journal of Accounting and Economics, 10(1), 3-36. https://doi.org/10.1016/0165-4101(88)90021-3

DeAngelo, L. E. (1981a). Auditor independence, "low balling", and disclosure regulation. Journal of Accounting and Economics, 3(2), 113-127. https://doi.org/10.1016/0165-4101(81)90009-4

DeFond, M., \& Jiambalvo, J. (1994). Debt covenant violations and manipulations of accruals. Journal of Accounting and Economics, 17(1-2), 145-176. https://doi.org/10.1016/0165-4101(94)90008-6

DeFond, M., \& Subramanyam, K. (1998). Auditor change and discretionary accruals. Journal of Accounting and Economics, 25(1), 35-67. https://doi.org/10.1016/S0165-4101(98)00018-4

Dye, R. A. (1991). Informationally motivated auditor replacement. Journal of Accounting and Economics, 14(4), 347-374. https://doi.org/10.1016/0165-4101(91)90008-C

Dodgson, M. K., Agoglia, C. P., Bennett, G. B., \& Cohen, J. R. (2020). Managing the auditor-client relationship through partner rotations: The experiences of audit firm partners. The Accounting Review, 95(2), 89-111. https://doi.org/10.2308/accr-52556

Emby, C., \& Favere-Marchesi, M. (2010). Review partners and engagement partners: The interaction process in engagement quality review. Auditing: A Journal of Practice \& Theory, 29(2), 215-232. https://doi.org/10.2308/aud.2010.29.2.215

FN-GUIDE (n.d.). https://www.fnguide.com

Francis, J. R., \& Wilson, E. R. (1988). Auditor changes: A joint test of theories relating to agency costs and auditor differentiation. The Accounting Review, 63(4), 663-682. https://www.jstor.org/stable/247906

Ghosh, A., \& Tang, C. Y. (2015). Auditor resignation and risk factors. Accounting Horizons, 29(3), 529-549. https://doi.org/10.2308/acch-51074

Gipper, B., Hail, L., \& Leuz, C. (2020). On the economics of mandatory audit partner rotation and tenure: Evidence from PCAOB data (Stanford University Graduate School of Business Research Paper, No. 17-56). https://ssrn.com/abstract=3023725

Higgs, J. L., \& Skantz, T. R. (2006). Audit and nonaudit fees and the market's reaction to earnings announcements. Auditing: A Journal of Practice \& Theory, 25(1), 1-26. https://doi.org/10.2308/aud.2006.25.1.1

International Federation of Accountants. (2009). International standard on auditing 220: Quality control for an audit of financial statement. https://www.ifac.org/system/files/publications/files/A011\%20 2012\%20IAASB\%20Handbook\%20ISA\%20220.pdf

Jeong, D. S., \& Lee, J. E. (2019). Effects of engagement partner's audit experiences on audit quality, as combined with auditor quality controls at engagement- and audit firm-levels. Study on Accounting, 
Taxation \& Auditing, 61(3), 1-31 (in Korean). https://www.kci.go.kr/kciportal/ci/sereArticleSearch/ ciSereArtiView.kci?sereArticleSearchBean.artiId=ART002506487

Johnstone, K. M. (2000). Client acceptance decisions: Simultaneous effects of client business risk, audit risk, auditor business risk, and risk adaptation. Auditing: A Journal of Practice \& Theory, 19(1), 1-25. https://doi.org/10.2308/aud.2000.19.1.1

Johnstone, K. M., \& Bedard, J. C. (2003). Risk management in client acceptance decisions. The Accounting Review, 78(4), 1003-1025. https://doi.org/10.2308/accr.2003.78.4.1003

Kim, Y. S., Kang, S. A., \& Park, S. H. (2021). The effect of management style on financial statement comparability: Evidence from Korean business groups. Asia-Pacific Journal of Accounting and Economics, 28(4), 454-471. https://doi.org/10.1080/16081625.2019.1566870

Kinney, W. R., \& Libby, R. (2002). Discussion of the relation between auditors' fees for nonaudit services and earnings management. The Accounting Review, 77(Suppl. 1), 107-114. https://doi.org/10.2308/accr.2002.77.s-1.107

Kothari, S., Leone, A., \& Wasley, C. (2005). Performance matched discretionary accrual measures. Journal of Accounting and Economics, 39(1), 163-197. https://doi.org/10.1016/j.jacceco.2004.11.002

Krishnan, J. (1994). Auditor switching and conservatism. The Accounting Review, 69(1), 200-215. https://www.jstor.org/stable/248267

Lei, D., Zhou, Y., \& Wang, Y. (2000). Auditor-client disagreements, auditor resignations, and audit fees changed by successor auditors. Journal of Applied Business Research, 36(1), 15-28. https://doi.org/10.19030/jabr.v36i1.10321

Lennox, C., Wang, C., \& Wu, X. (2020). Opening up the "black-box" of audit firms: The effects of audit partner ownership on audit adjustments. Journal of Accounting Research, 58(5), 1299-1341. https://doi.org/10.1111/1475-679X.12333

Lustgarten, S., \& Shon, J. (2013). Do abnormal accruals affect the life expectancy of audit engagements? Review of Quantitative Finance and Accounting, 40(3), 443-466.

https://doi.org/10.1007/s11156-012-0276-1

Matsumura, E. M., \& Tucker, R. R. (1995). Second partner review: An analytical model. Journal of Accounting, Auditing \& Finance, 10(1), 173-200. https://doi.org/10.1177/0148558X9501000113

Mitra, S., Jaggi, B., \& Al-Hayale, T. (2016). Auditor’s downward switch, governance, and accounting conservatism. Journal of Accounting, Auditing \& Finance, 31(4), 551-581. https://doi.org/10.1177/0148558X15590227

Public Company Accounting Oversight Board. (2009). Auditing standard No 7: Engagement quality review (AS No. 7). PCAOB Release 2009-004. Washington. https://pcaobus.org/oversight/standards/ archived-standards/pre-reorganized-auditing-standards-interpretations/details/auditing-standardno-7_1836

Schwartz, K. B., \& Menon, K. (1985). Auditor switches by failing firms. The Accounting Review, 60(2), 248-261. https://www.jstor.org/stable/246789

Simon, D. T., \& Francis, J. R. (1988). The effects of auditor change on audit fees: Tests of price cutting and price recovery. The Accounting Review, 63(2), 255-268. https://www.jstor.org/stable/248104

Simunic, D. A. (1980). The pricing of audit services: Theory and evidence. Journal of Accounting Research, 18(1), 161-190. https://www.doi.org/10.2307/2490397

Simunic, D. A., \& Stein, M. T. (1996). The impact of litigation risk on audit pricing: A review of the economics of and the evidence. Auditing: A Journal of Practice \& Theory, 15, 119-133.

Sung, O. H. (2007). Estimation of risk-adjusted discount rate for the technology valuation of smallsized venture firm. In Commercialization and Transfer of Technology: Major Country Case Studies (pp. 231-240). Nova. http://www.novapublishers.org/catalog/product_info.php?products_id=5586

Tucker, R. R., \& Matsumura, E. M. (1997). Second-partner review: An experimental economics investigation. Auditing: A Journal of Practice \& Theory, 16(1), 79-98. 
Warner, J. B., Watts, R. L., \& Wruck, K. H. (1988). Stock prices and top management changes. Journal of Financial Economics, 20, 461-492. https://doi.org/10.1016/0304-405X(88)90054-2

Weisbach, M. S. (1988). Outside directors and CEO turnover. Journal of Financial Economics, 20, 431460. https://doi.org/10.1016/0304-405X(88)90053-0

Wells, P. (2002). Earnings management surrounding CEO changes. Accounting and Finance, 42(2), 169-193. https://doi.org/10.1111/1467-629X.00073

Woo, E. S., \& Koh, H. C. (2001). Factors associated with auditor changes: A Singapore study. Accounting and Business Research, 31(2), 133-144. https://doi.org/10.1080/00014788.2001.9729607

Zhang, J. H. (2018). Accounting comparability, audit effort, and audit outcomes. Contemporary Accounting Research, 35(1), 245-276. https://doi.org/10.1111/1911-3846.12381

\section{APPENDIX}

Variable definitions

\begin{tabular}{|c|c|}
\hline Variables & Definitions \\
\hline EQCRH & EQCR hours scaled by total audit hours, including EQCR hours \\
\hline$A C$ & One if firm $i$ changes its auditor, zero otherwise \\
\hline$M C$ & One if firm $i$ changes its CEO, zero otherwise \\
\hline FEE & Natural $\log$ of audit fees \\
\hline$A b F E E$ & Differences between actual audit fees and normal audit fees calculated by Eq. (2) \\
\hline SIZE & Natural log of total assets \\
\hline$L E V$ & Total liabilities scaled by total assets \\
\hline$R O A$ & Net accounting income scaled by beginning of year total assets \\
\hline CFO & Cash flows from operations scaled by beginning of year total assets \\
\hline GROW & Difference between current sales and previous sales scaled by previous sales \\
\hline BIG4 & One if the external auditor of firm $i$ is a Big 4 audit firm, zero otherwise \\
\hline INVREC & Inventories and receivables scaled by total assets \\
\hline LIQUID & Current assets scaled by current liabilities \\
\hline LOSS & One if the net accounting income of firm $i$ is negative, zero otherwise \\
\hline FIRST & One if the audit engagement of firm $i$ is initial, zero otherwise \\
\hline CON & One if firm $i$ issues its consolidated financial statements, zero otherwise \\
\hline$E Q H D A L$ & $\begin{array}{l}\text { One if the EQCR hours of firm } i \text { are high and discretionary accruals according to } \\
\text { Kothari et al. (2005) are low, zero otherwise }\end{array}$ \\
\hline BusinessR & One if firm $i$ is listed on KOSDAQ, zero if firm $i$ is listed on KOSPI \\
\hline LitigationR & One if firm $i$ discloses the occurrence of litigation, zero otherwise \\
\hline AgencyC & One if firm $i$ is a member firm of Korean business groups, zero otherwise \\
\hline
\end{tabular}

